\title{
SEVERAL TOOLS USED TO CONTROL COTTON LEAFWORM, Spodoptera littoralis (BOISD.) AND AMERICAN BOLLWORM, Helicoverpa armigera (HÜB.) IN PEANUT FIELDS.
}

(Received: 21. 8. 2011)

\author{
By \\ H. M .H. Al-Shannaf and A. E. Ammar \\ Plant Protection Research Institute, Agriculture Research Center, Dokki , Giza, Egypt
}

\begin{abstract}
The present paper discusses the integrated control of cotton leafworm, Spodoptera littoralis and Americam bollworm, Helicoverpa armigera using four sprayer types $i$.e. (Power knapsack sprayer EFCO-16 (60 \& 80) L. /fed., Manual sprayer (UNX-18 100L/fed.) and conventional motor sprayer 300L/fed. Moreover, the insecticides (Dipel DF , Radical, Dursban\& Consult and Dursban only) in peanut fields were tried in new Salhea region ,Sharkia Governorate.

Data indicated that Radical compound gave the highest initial reduction percentage and gave the best tool of integrated control of $S$. littoralis and $H$. armigera followed by Dursban \& Consult and Dursban only on peanut fields. While the lowest initial reduction percentage of $S$. littoralis and $H$. armigera recorded with Dipel DF in 2010 and 2011. On the other hand the highest mean residual reduction percentage (as a latent effect) was recorded with Radical compound in both seasons 2010 and 2011 treated by Dursban \& Consult and Dursban only for S. littoralis and H. armigera. Meanwhile, the lowest mean residual reduction percentage was recorded for Dipel DF.

While,the lowest influence of compounds on predators was recorded with Dipel DF followed by Radical (bioinsecticid)compared with Dursban\& Consult and Dursban only (conventional insecticides) in 2010 - 2011 seasons.

The obtained results revealed that the highest percentages of covering peanut plants were $62-61 \%$ obtained using power knapsack motor sprayer (EFCO - 16) $60 \mathrm{~L} . /$ fed. followed by $59-60,57-59$ and $45-42 \%$ for EFCO - 16 (80 L./fed.), UNX-18 and conventional motor sprayer with all used compounds, respectively. On the other hand, the lowest losses on land were recorded with EFCO - 16 (60 L. / fed.) $15-17 \%$ followed by $16-18,21-22$ and 27- 28\% using EFCO - 16 (80 L./fed.), UNX - 18 and conventional motor sprayer, respectively.

Also, the obtained results revealed that the lowest contamination for applicator was recorded using the manual sprayer (NUX - 18) $20-21 \%$ contamination on the appreciator followed by $22-23,22-25$ and 27-31\% with using EFCO-16 (60 and 80 L./fed.) and conventional motor sprayer, respectively.
\end{abstract}

Key words: Several tools, $(C L W)$ Spodoptera littoralis, $(A B W)$ Helicoverpa armigera, Peanut

\section{INTRODUCTION}

The Egyptian cotton leafworm, $S$. littoralis (Boisd.) and the American bollworm, H. armigera (Hub.) have been considered a serious economic pests of cotton, many field crops and vegetables in Egypt. Although they are active all the year round without a hibernation period attacking cotton plants and cause many losses of many hosts from other crops and vegetables in Egypt,( Alford, 2000; AlShannaf, 2007 and Amin, 2007).

Helicoverpa armigera is the most widely distributed and considered a pest of major importance in most areas where it is damaging a wide variety of food, fiber and oil seeds. The effect of three biocides and two insect growth regulators were evaluated against $H$. armigera and their side effects against some common predators (Pearson, 1958).

Hindy(1998) assessed two groups of sprayer types. The first group included three recommended techniques with satisfactory results as follows: Knapsack motor sprayer, Arimistu flow No2, No3 and Micro ULVA sprayer. The second group included lower operated (CP3) A,B and $\mathrm{C}$. The obtained results indicated that, a great relationship was found between the coverage indicator on plants and the bioefficiency result, which confirmed the importance of proper selection of a spraying equipment and its vital role affecting cotton leafworm control on cabbage. 
Badr et al., 1999 and Hindy et al., 1999 used a hand lever operated, conventional hydraulic Knapsack sprayed Mitabi, Arimistu and Micro ULVA sprayer for controlling cotton leafworm on clover plants. The results showed that using knapsack motor sprayer gave higher reduction for small larvae more than using Micro ULVA. Ammar, 2007 tested spraying equipment "Semco sprayer" with hand lance at 6 L./fed., and conventional sprayer at $300 \mathrm{~L}$./fed., using of preempt and jojoba (plant extract) insecticide .The data indicated that "Semco sprayer" with hand lance gave satisfactory coverage on tomato plants ,but in the case of conventional sprayer it caused a moderately reduction of weight fly compared with "Semco sprayer".

The aim of this study was to evaluate the performance of some different sprayers using different insecticides as a tool of control for cotton leafworm and American bollworm in peanut fields.

\section{MATERIALS AND METHODS}

The research took place at the new Salheia, Sharkia Governorate during the summer of 2010 and 2011 on peanut plants.

\subsection{The pesticide used}

\subsubsection{The chemical insecticide}

Chlorpyrifos methyl, (Dursban EC 48\%) used at a rate of $1000 \mathrm{ml} / \mathrm{fed}$.)

\subsubsection{Insect growth regulator}

Benzoylurea, ,Hexaflumuron (Consult 10\% EC) used at a rate of $200 \mathrm{ml} / \mathrm{fed}$.

\subsubsection{The bioinsecticide}

2.1.3.1. Radical $0.5 \%$ EC (Avermectin) used at a rate of $200 \mathrm{ml} / 100 \mathrm{~L}$. water).

2.1.3.2.Dipel $\mathrm{DF}^{\circledR}$, Bacillus thuringiensis Kurstaki (32,258 Potency I.U./mg) WP used at a rate of $200 \mathrm{~g} / \mathrm{fed}$.

\subsection{Experimental design}

Field experiments were carried out in the new Salheia-region, Sharkia Governorate on CLW and $\mathrm{ABW}$ in peanut fields. Field treatments were chosen as 4 fed. divided into 4 blocks. The first block was treated with bio-insecticide (Dipel DF), the second block was treated with Radical compound, the third block was treated with
Dursban \& Consult and the forth block was treated with Dursban only using the recommended doses. Each block was treated with 4 different sprayer types (Power knapsack sprayer (EFCO16) used at a rate of 60 and $80 \mathrm{~L}$. water/fed., Manual sprayer (UNX-18) was used at a rate of $100 \mathrm{~L}$. water/fed. and conventional motor sprayer used at a rate of $300 \mathrm{~L}$. water/fed.. Each treatment was divided in to three replicates $\left(262.5 \mathrm{~m}^{2}\right.$ for each replicate) and untreated plots during 2010 and 2011 seasons. The experimental area of each treatment was sprayed at appearance of the $1^{\text {st }}, 2^{\text {nd }}$ and $3^{\text {rd }}$ instar larvae of CLW. Previous design was carried out on another area (4 fed) in the same region infested with $\mathrm{ABW}$ at the $1^{s t}, 2^{\text {nd }}$ and $3^{r d}$ instar larvae on peanut plants.

The number of larvae of S.littoralis and $H$. armigera species and associated predators (The harmful effect of the tested compounds against some predators, e.g., aphidlion, Chrysoperla carnea; beetles, Coccinella spp.; anthrocoride bugs Orious spp.; staphylinid beetle, Peaderus alfierii; Scymnus spp. and true spiders) were counted in each treatment, before the treatment and after 3,7 and 10 days of bio-insecticides (Dipel DF and Radical).On the other hand 24 hours, 7 and 10 days after treatment with (Dursban \& Consult) and Dursban of 25 hills for each replicate and in the untreated plots. The initial reductions were calculated for $24 \mathrm{~h}$. of conventional insecticide and 3 days for bioinsecticide, the mean residual reduction was calculated 7 and 10 days after the treatment. Reduction percentages were calculated according to the equation of Henderson and Tilton (1955).

\subsection{Spraying applications}

\subsubsection{Power knapsack sprayer (EFCO-16)}

A medium spraying volume was applied pneumatic with a sprayer on the targeted plantations. Specifications and information are contained in Table (1).

\subsubsection{Manual sprayer (UNX-18)}

The sprayer was tested as a target sprays in order to evaluate their spraying quality. It is classified with the pump handle by a crankshaft mechanism. The technical data are presented in Table (1).

Table(1):Technical data of the equipment used against cotton leafworm and American bollworm in peanut fields.

\begin{tabular}{|l|c|c|c|c|}
\hline \multicolumn{1}{|c|}{ Data } & \multicolumn{2}{|c|}{$\begin{array}{c}\text { Power knapsack sprayer } \\
\text { (EFCO-16) }\end{array}$} & $\begin{array}{c}\text { Manual sprayer (UNX- } \\
\text { 18) }\end{array}$ & $\begin{array}{c}\text { Conventional motor } \\
\text { sprayer }\end{array}$ \\
\hline Spray volume L/ fed & 60 & 80 & 100 & 300 \\
\hline Swath width (m) & 5.0 & 5.0 & 1.0 & 3.0 \\
\hline Mean working speed (km/h) & 2.4 & 2.4 & 2.4 & 2.4 \\
\hline Flow rate (L/min) & 2.860 & 3.810 & 0.952 & 8.570 \\
\hline Spray height (m) & 0.50 & 0.50 & 0.50 & 0.50 \\
\hline
\end{tabular}

Mean working speed $\sim \pm 5$ 


\subsubsection{Conventional motor sprayer}

Spray gun of motor sprayer is composed mainly of a chemical tank (300 liters) and reciprocating pump powered by $5 \mathrm{Hp}$ benzene motor .The spray gun is connected to the pump by a 40-80m.lon rubber hose. The pump could provide pressure up to $30 \mathrm{~kg} / \mathrm{cm}^{2}$.

\subsubsection{Description of sampling line}

The sampling line consisted of 6 wire holders fixed in a diagonal line inside each treatment to collect sprayed chemicals.

Three sensitive cards were distributed on some plants (right, middle and left) at distances of one meter. Water sensitive paper (Syngenta) with the wire holders were fixed in "L shap" on the top of the wire holders. All cards were collected and transferred carefully to the laboratory for measurements and calculation of the deposited droplets. While sensitive cards were fixed on the applicator (Head, Thorax and legs) for measuring of contamination deposit (Ammar, 2003). On the other hand, the number and size was considered droplet on cards were measured with a special scaled monocular lens $\left(\right.$ Struben $\left.^{\circledR}\right)$ with magnification of X 15 (Abou Amer, 1993), spread factor was estimated (Gehan, 2000).

\section{RESULTS AND DISCUSSION}

In peanut fields, two methods of integrated control were used of $S$. littoralis and $H$. armigera, the $1^{\text {st }}$ using four sprayer types $i . e$., (Power knapsack sprayer EFCO-16 (60 \& 80 L./fed.). manual sprayer (UNX-18 100L/fed) and conventional motor sprayer $300 \mathrm{~L} / \mathrm{fed}$. The $2^{\text {nd }}$ methed using the insecticides (Dipel DF, Radical,Dursban\& Consult and Dursban only).

\subsection{Spray coverage on peanut plants}

Results in Table (2) revealed that, the highest percentage covering peanut plants were 62-61\% obtained using the power Knapsack motor sprayer (EFCO-16) 60L./fed. Low volume mean droplets (VMD) of 120-135 $\mu$ and the highest number of droplets was $163-190 \mathrm{~N} / \mathrm{cm}^{2}$. The previously mentioned results, showed that the highest general means of reduction were (90.00-89.67), (85.33$85.33),(82.67-82.33)$ and $(17.67-17.33 \%)$ respectively for Radical ,Dursban \&Consult, Dursban and Dipel DF for CLW in 2010 and 2011 seasons. While, they were (88.00-82.67),(83.67$82.33),(75.00-79.00)$ and $(10.00-7.00 \%)$ obtained with Radical, Dursban mixed with Consult, Dursban and Dipel DF for controlling ABW in 2010 and 2011 seasons,. Also, the highest general mean reduction for the predators were (64.0063.67),(56.00-7.33),(49.00-47.33) and (3.33-
$2.00 \%)$ respectively recorded with Dursban mixed with Consult, Dursban, Radical and Dipel DF in both seasons.

Data in Table (2) indicated that the use of EFCO-16 80L./fed. recorded the plant coverage (60-59\%),VMD (145-165 $\mu)$ and N/cm2 (172200). The general mean reductions of CLW were (88.67-88.33),(84.67-83.00),(81.67-81.33) and (16.00-14.67\%) for Radical, Dursban mixed with Consult, Dursban and Dipel DF in 2011 season, respectively. Also the general mean reductions of ABW were (86.00-82.33),(82.67-81.33), (74.00$77.33)$ and (9.67-6.00\%) for Radical, Dursban \& Consult, Dursban and Dipel DF, in 2010 and 2011 seasons ,respectively. While the general mean reductions of the predators were (58.6761.00),(55.67-55.67),(44.00-43.67) and (2.00$1.67 \%$ ) for Dursban mixed with Consult, Dursban, Radical and Dipel DF, 2010 and 2011 seasons, respectively.

Data in Table (2) cleared the effect using Manual sprayer (UNX-18)100L./fed., the percentage covering of peanut plants were $(57.00$ $58.00 \%),(210-230)$ VMD and $(75-83) \mathrm{N} / \mathrm{cm}^{2}$. On the other hand, this sprayer gave the moderate general mean reduction.

The general mean reductions of CLW were (85.67-85.00), (84.00-82.33), (80.33-79.67) and (8.33-11.33\%) for Radical , Dursban\& Consult, Dursban and Dipel DF during 2010 and 2011 seasons, respectively. Reductions of $H$. armigera were (83.00-79.67), (80.67-79.33), (71.67-75.67) $(8.33-5.67 \%)$ in both seasons, respectively. While reductions of predators were (58.67-58.67), (54.3351.00), (39.33-38.67) and (2.00-1.67\%) for Dursban \& Consult, Dursban, Radical and Dipel DF during 2010 and 2011 ,respectively.

On the other hand, using conventional motor sprayer, the results showed the lowest mean reduction. The lowest covering of peanut plants were $(42.00-45.00 \%)$, low of $\mathrm{N} / \mathrm{cm}^{2}(10-20)$ and biggest droplets VMD $(970-980 \mu)$. From the previously mentioned results, the conventional motor sprayer recorded the lowest efficiency for controlling CLW and ABW in both seasons. Vadivelu et al. , 1986 evaluated the effectiveness of using high volume (knapsack sprayer 225 L./ha), low volume (Aspee power sprayer 60L./ha) and ultra- low volume (A fogair sprayer $12.5 \mathrm{~L} . / \mathrm{ha})$ for controling cotton pests using conventional insecticides. Results indicated that, the aphid lion, Chrysoperla carnna and cicadellid populations were higher in plots treated with knapsack sprayer than in those treated with the other two sprayers. The bade kapas content was 
the lowest droplet density and the good coverage in plots treated with the Fogair sprayer. In a comparison of high low volume, low -volume and ultralow-volume pesticide sprayer trials in cotton in India, found that ultralow-volume sprayers were the most economical.

\subsection{Losses on land}

Data in Table (2) indicated that, the lowest losses efficiency of insecticides on land recorded with EFCo-16 60L/fed.were (15-17\%) sprayed by EFCO-16 (80 L/fed.) were (16-18\%),Manual sprayer (UNX-18)100L/fed. were (21.-22\%). On the other hand, using conventional motor sprayer, recorded the highest percentage of losses on land were $(27-28 \%)$

\subsection{Contamination of applicator}

The obtained results revealed that the lowest contamination of applicator $(20-21 \%)$ was recorded with using the manual sprayer (UNX-18) $100 \mathrm{~L} / \mathrm{fed}$. while the using of power Knapsack sprayer (EFCO-16) 60 and $80 \mathrm{~L} /$ fed. recorded the moderate contamination (22-23\%) and ((22-25\%), respectively. On the other hand, using the conventional motor sprayer recorded the highest contamination on the applicator (27.5-31\%). Ammar, 2007 tested two sprayers, semco sprayer with hand lance at $6 \mathrm{~L} / \mathrm{fed}$. and conventional sprayer at $300 \mathrm{~L} / \mathrm{fed}$. Semco sprayer gave satisfactory coverage on tomato plants amounted 93.75 and $90.70 \%$ and minimum lost compound

Table (2): Spray coverage produced by different sprayers and spraying volume with different insecticides on peanut plants for controlling cotton leafworm and American bollworm .

\begin{tabular}{|c|c|c|c|c|c|c|c|c|c|c|c|c|c|}
\hline \multirow{3}{*}{\multicolumn{2}{|c|}{\begin{tabular}{|c|} 
Equipment \\
$\begin{array}{c}\text { Spray volume } \\
\text { L./Fed. }\end{array}$ \\
Droplets \\
\end{tabular}}} & \multicolumn{6}{|c|}{$\begin{array}{l}\text { Power knapsack sprayer (EFCO- } \\
\text { 16) }\end{array}$} & \multirow{2}{*}{\multicolumn{3}{|c|}{$\begin{array}{c}\begin{array}{c}\text { Manual } \\
\text { sprayer } \\
\text { (UNX-18) }\end{array} \\
100\end{array}$}} & \multirow{2}{*}{\multicolumn{3}{|c|}{$\begin{array}{c}\begin{array}{c}\text { Conventional motor } \\
\text { sprayer }\end{array} \\
\mathbf{3 0 0}\end{array}$}} \\
\hline & & \multicolumn{3}{|c|}{60} & \multicolumn{3}{|c|}{80} & & & & & & \\
\hline & & $\sum \frac{1}{a}$ & $\sum_{\mathrm{Z}}^{\mathbf{Z}}$ & $\frac{8}{Z}$ & $\sum_{i}^{=}$ & $\sum_{N}^{\Sigma_{N}}$ & Z & $\sum_{>}^{=}$ & $\bar{\Xi}_{N}$ & $\frac{0^{\circ}}{Z}$ & $\sum \frac{=}{a}$ & 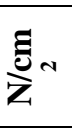 & $\frac{0}{Z}$ \\
\hline \multirow{6}{*}{$\frac{\sqrt{0}}{0}$} & 1 & 135 & 163 & 62 & 165 & 172 & 60 & 230 & 75 & 58 & 980 & 14 & 42 \\
\hline & 2 & 148 & 40 & 15 & 171 & 52 & 18 & 245 & 28 & 22 & 995 & 9 & 27 \\
\hline & 3 & 103 & 60 & 23 & 130 & 62 & 22 & 175 & 26 & 20 & 870 & 10 & 31 \\
\hline & 4 & \multicolumn{3}{|c|}{$17.67 / 17.33$} & \multicolumn{3}{|c|}{$16.00 / 14.67$} & \multicolumn{3}{|c|}{$8.33 / 11.33$} & \multicolumn{3}{|c|}{$9.00 / 11.33$} \\
\hline & 5 & \multicolumn{3}{|c|}{$10.00 / 7.00$} & \multicolumn{3}{|c|}{$9.67 / 6.00$} & \multicolumn{3}{|c|}{$8.33 / 5.67$} & \multicolumn{3}{|c|}{$7.00 / 4.83$} \\
\hline & 6 & \multicolumn{3}{|c|}{$3.33 / 2.00$} & \multicolumn{3}{|c|}{$2.00 / 1.67$} & \multicolumn{3}{|c|}{$2.00 / 1.67$} & \multicolumn{3}{|c|}{$1.67 / 1.33$} \\
\hline \multirow{6}{*}{ 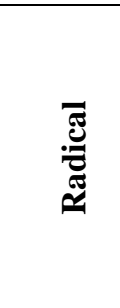 } & 1 & 130 & 170 & 61 & 158 & 178 & 60 & 225 & 78 & 58 & 978 & 15 & 42 \\
\hline & 2 & 141 & 47 & 17 & 168 & 49 & 16 & 236 & 29 & 22 & 985 & 10 & 28 \\
\hline & 3 & 100 & 63 & 22 & 126 & 71 & 24 & 167 & 27 & 20 & 950 & 11 & 30 \\
\hline & 4 & \multicolumn{3}{|c|}{$90.00 / 89.67$} & \multicolumn{3}{|c|}{$88.67 / 88.33$} & \multicolumn{3}{|c|}{$85.67 / 85.00$} & \multicolumn{3}{|c|}{$81.67 / 82.00$} \\
\hline & 5 & \multicolumn{3}{|c|}{$88.00 / 82.67$} & \multicolumn{3}{|c|}{$86.00 / 82.33$} & \multicolumn{3}{|c|}{$83.00 / 79.67$} & \multicolumn{3}{|c|}{$81.33 / 78.67$} \\
\hline & 6 & 49.0 & $0 / 47$ & & 44.0 & $00 / 43$ & & 39.3 & $33 / 3$ & & & $33 / 3$ & \\
\hline & 1 & 125 & 187 & 61 & 156 & 197 & 59 & 217 & 80 & 59 & 975 & 18 & 45 \\
\hline & 2 & 135 & 49 & 16 & 163 & 55 & 17 & 225 & 29 & 21 & 980 & 11 & 27.5 \\
\hline 可 & 3 & 98 & 71 & 23 & 120 & 80 & 24 & 165 & 27 & 20 & 940 & 11 & 27.5 \\
\hline ن & 4 & 85.3 & $3 / 85$ & & 84.6 & $57 / 83$ & & 84.0 & $00 / 8$ & & & $33 / 8$ & \\
\hline & 5 & 83.6 & $7 / 82$ & & 82.6 & $57 / 81$ & & 80.6 & $57 / 7$ & & & $00 / 7$ & \\
\hline & 6 & 64.0 & $0 / 63$ & & 58.6 & $57 / 61$ & & 58.6 & $57 / 5$ & & & $33 / 5$ & \\
\hline & 1 & 120 & 190 & 61 & 145 & 200 & 59 & 210 & 83 & 57 & 970 & 20 & 44 \\
\hline & 2 & 133 & 52 & 17 & 156 & 53 & 16 & 220 & 32 & 22 & 990 & 13 & 28 \\
\hline ฮี & 3 & 100 & 72 & 22 & 118 & 84 & 25 & 162 & 30 & 21 & 930 & 13 & 28 \\
\hline$\stackrel{2}{3}$ & 4 & 82.6 & $7 / 82$ & & 81.6 & $57 / 81$ & & 80.3 & $33 / 7$ & & & $33 / 7$ & \\
\hline$\tilde{a}$ & 5 & 75.0 & $0 / 75$ & & 74.0 & $00 / 77$ & & 71.6 & $57 / 7$ & & & $33 / 7$ & \\
\hline & 6 & 56.0 & $0 / 57$ & & 55.6 & $57 / 55$ & & 54.3 & $33 / 5$ & & & $00 / 5$ & \\
\hline $\begin{array}{l}1=\text { Cover } \\
4=\text { Gener } \\
5=\text { Gener } \\
6=\text { Gener } \\
\mathrm{N} / \mathrm{cm}^{2}=\mathrm{N}\end{array}$ & $\begin{array}{l}\text { n plan } \\
\text { an re } \\
\text { ean re } \\
\text { an re } \\
\text { er of c }\end{array}$ & $\begin{array}{l}\text { ion of } \\
\text { tion o } \\
\text { ion of } \\
\text { lets/cr }\end{array}$ & $\begin{array}{l}\text { S. lit } \\
H . a \\
\text { pred }\end{array}$ & 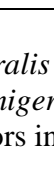 & $\begin{array}{l}2=\text { Loss } \\
\text { n } 2010 \\
\text { in } 2010 \\
2010 \text { an }\end{array}$ & $\begin{array}{l}\text { es on } 1 \\
\text { and } 20 \\
0 \text { and } 2 \\
d 2011\end{array}$ & & $\begin{array}{l}\text { VMD } \\
\text { N\%= }\end{array}$ & $=\mathrm{V}$ & & ontan & ation & plicato \\
\hline
\end{tabular}


tested between plants accounted for $0.59-1.48 \%$ and very poor contamination on the applicator by $5.66-8.14 \%$ of spray deposit. However conventional sprayer percentage of spray deposit ranged presented by 42.7 and $34.20 \%$ on tomato plants, lost on land between tomato plants was 17.95 and $15.60 \%$, and contamination of applicator reached 47.43 and $41.7 \%$. Data showed that semco sprayer gave excellent control against whitefly, meanwhile conventional sprayer gave percent reduction ranged between 59.40 and $56.60 \%$ with prempet insecticide.

\subsection{Efficiency using different sprayer types on reduction of $S$. littoralis}

Results in Table (3) indicated that, using the EFCO-16 $80 \mathrm{~L} / \mathrm{fed}$. recorded the highest initial reduction (93.00-91.00)\& (92.00-91.00);(89.00$88.00) \&(89.00-86.00), \quad(87.10086 .0) \quad \& \quad(87.00-$ $85.00)$ and $(8.00-78.00) \&(9.00-8.00 \%)$ for Radical, Dursban+ Consult, Dursban and Dipel DF during 2010 and 2011 seasons, respectively.

The moderate initial reduction recorded by using the UNX-18 100L/fed. were (91.00-90.00), (88.00-86.00), (82.00-81.00) and (5.00-6.00\%) for Radical, Dursban\& Consult, Dursban and Dipel DF in 2010 and 2011 seasons, respectively.

The conventional motor sprayer recorded the lowest initial reduction of $S$. littoralis with all compounds during both seasons. Data in Table (3) showed that, the highest mean reduction obtained with using EFCO-16 60 L/fed. were (88.5150- 83.50),(80.50-80.00)and (17.50-21.50\%) for Radical, Dursban+ Consult, Dursban and Dipel DF in both seasons 2010 and 2011 ,respectively. On the other hand, the lowest mean residual of reduction recorded with using conventional motor sprayer were (80.50-78.50),(77..50-78.00),(75.5076.00) and (11.00-13.50\%) for Dursban+ Consult, Radical, Dursban and Dipel DF during 2010and 2011 seasons, respectively. Dipel DF, the lowest mean residual of reduction obtained with using UNX-18 were10.00 \% in 2010 season only. Sprayers EFCO-16 80 L/fed. and UNX-18 $100 \mathrm{~L} /$ fed. for controlling $\mathrm{CLW}$ and $\mathrm{ABW}$ recorded moderate effects with all tested compounds.

\subsection{Efficiency using different sprayer types on reduction of $H$. armigera}

The data in Table (4) cleared that, the highest initial reduction was recorded with using the EFCO-16 60L/fed. (90.00-89.00),(86.00-87.00), (78.00-83.00) and (4.00-4.00 \%) for Radical, Dursban+ Consult ,Dursban and Dipel DF in 2010 and 2011 seasons, respectively. But the lowest initial reduction obtained with using the same sprayer type were (80.00-87.00),(80.00$80.00),(70.00-76.00)$ and $(3.00-2.50 \%)$ for Radical, Dursban+ Consult, Dursban and Dipel DF in both seasons 2010 and 2011,respectively.

The highest mean residual of reduction recorded using the EFCO-16 60L/fed. followed

Table (3): Reduction percentage of bioinsecticide and conventional insecticides on Spodoptera littoralis larvae in peanut fields during 2010 and 2011 seasons.

\begin{tabular}{|c|c|c|c|c|c|c|c|c|c|c|c|}
\hline \multirow{3}{*}{\multicolumn{2}{|c|}{$\begin{array}{l}\text { Compound } \\
\text { Sprayer type }\end{array}$}} & \multicolumn{5}{|c|}{2010} & \multicolumn{5}{|c|}{2011} \\
\hline & & \multicolumn{2}{|c|}{ Initial\% } & \multicolumn{3}{|c|}{ Residual\% } & \multicolumn{2}{|c|}{ Initial\% } & \multicolumn{3}{|c|}{ Residual\% } \\
\hline & & 1 day & $\begin{array}{c}3 \\
\text { day }\end{array}$ & $\begin{array}{c}7 \\
\text { day }\end{array}$ & $\begin{array}{c}10 \\
\text { day }\end{array}$ & $\begin{array}{c}\text { Mean } \\
\text { residual }\end{array}$ & $\begin{array}{c}1 \\
\text { day }\end{array}$ & $\begin{array}{c}3 \\
\text { day }\end{array}$ & $\begin{array}{c}7 \\
\text { day }\end{array}$ & $\begin{array}{c}10 \\
\text { day }\end{array}$ & $\begin{array}{c}\text { Mean } \\
\text { residual }\end{array}$ \\
\hline \multirow{4}{*}{$\frac{\sqrt{1}}{0}$} & EFCO-16/60 L & & 8.00 & 12.00 & 23.00 & 17.50 & & 9.00 & 19.00 & 24.00 & 21.50 \\
\hline & EFCO-16/80 L & & 7.00 & 10.00 & 21.00 & 15.50 & & 8.00 & 16.00 & 20.00 & 18.00 \\
\hline & UNX-18/100 L & & 5.00 & 8.00 & 12.00 & 10.00 & & 6.00 & 12.00 & 16.00 & 15.00 \\
\hline & Convintional/300 L & & 5.00 & 10.00 & 12.00 & 11.00 & & 7.00 & 12.00 & 15.00 & 13.50 \\
\hline \multirow{4}{*}{ 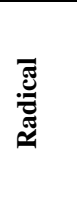 } & EFCO-16/60 L & & 93.00 & 89.00 & 88.00 & 88.50 & & 92.00 & 89.00 & 88.00 & 88.50 \\
\hline & EFCO-16/80 L & & 91.00 & 89.00 & 86.00 & 87.50 & & 91.00 & 88.00 & 86.00 & 87.00 \\
\hline & UNX-18/100 L & & 91.00 & 84.00 & 82.00 & 83.00 & & 90.00 & 83.00 & 82.00 & 82.50 \\
\hline & Convintional/300 L & & 90.00 & 79.00 & 76.00 & 77.50 & & 90.00 & 79.00 & 77.00 & 78.00 \\
\hline \multirow{4}{*}{ 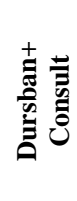 } & EFCO-16/60 L & 89.00 & & 86.00 & 81.00 & 83.50 & 89.00 & & 86.00 & 81.00 & 83.50 \\
\hline & EFCO-16/80 L & 88.00 & & 86.00 & 80.00 & 83.00 & 86.00 & & 84.00 & 79.00 & 81.50 \\
\hline & UNX-18/100 L & 88.00 & & 84.00 & 80.00 & 82.00 & 86.00 & & 82.00 & 79.00 & 80.50 \\
\hline & Convintional/300 L & 86.00 & & 82.00 & 79.00 & 80.50 & 85.00 & & 80.00 & 77.00 & 78.50 \\
\hline \multirow{4}{*}{$\frac{\Xi}{\tilde{\Xi}}$} & EFCO-16/60 L & 87.00 & & 82.00 & 79.00 & 80.50 & 87.00 & & 81.00 & 79.00 & 80.00 \\
\hline & EFCO-16/80 L & 86.00 & & 80.00 & 79.00 & 79.50 & 85.00 & & 80.00 & 79.00 & 79.50 \\
\hline & UNX-18/100 L & 82.00 & & 81.00 & 78.00 & 79.50 & 81.00 & & 80.00 & 78.00 & 79.00 \\
\hline & Convintional/300 L & 78.00 & & 76.00 & 75.00 & 75.50 & 78.00 & & 77.00 & 75.00 & 76.00 \\
\hline
\end{tabular}


by UNX-18/ $100 \mathrm{~L} / \mathrm{fed}$. and conventional motor sprayer 300L/fed. with Radical, Dursban+ Consult, Dursban and Dipel DF in both seasons 2010 and 2011, respectively. Vadivelu, et al. 1986 evaluate the effectiveness of using high volume(knapsack sprayer $225 \mathrm{~L} / \mathrm{ha}$ ), low volume whitefly 1.27 adults/leaf population; while during the reproductive phase of cotton it was recorded the lowest bollworm incidence in shed fruiting bodies (14.50\%) and 14.2 and $6.40 \%$ incidence in open bolls and locule, respectively. The yield of seed cotton was highest in PS (14.5 q/ha).

Table (4): Reduction percentage of bioinsecticide and conventional insecticides on Helicoverpa armigra larvae in peanut bean fields during 2010 and 2011 seasons.

\begin{tabular}{|c|c|c|c|c|c|c|c|c|c|c|c|}
\hline \multirow{2}{*}{\multicolumn{2}{|c|}{ Compound }} & \multicolumn{5}{|c|}{2010} & \multicolumn{5}{|c|}{2011} \\
\hline & & \multicolumn{2}{|c|}{ Initial\% } & \multicolumn{3}{|c|}{ Residual\% } & \multicolumn{2}{|c|}{ Initial\% } & \multicolumn{3}{|c|}{ Residual\% } \\
\hline & Sprayer type & 1 day & 3 day & 7 day & 10 day & $\begin{array}{c}\text { Mean } \\
\text { residual }\end{array}$ & 1 day & 3 day & 7 day & 10 day & $\begin{array}{c}\text { Mean } \\
\text { residual }\end{array}$ \\
\hline \multirow{4}{*}{ 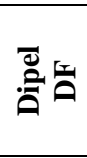 } & EFCO-16/60 L & & 4.00 & 12.00 & 14.00 & 13.00 & & 4.00 & 8.00 & 9.00 & 8.50 \\
\hline & EFCO-16/80 L & & 4.00 & 12.00 & 13.00 & 12.50 & & 3.00 & 6.00 & 9.00 & 7.50 \\
\hline & UNX-18/100 L & & 3.00 & 10.00 & 12.00 & 11.00 & & 3.00 & 6.00 & 8.00 & 7.00 \\
\hline & Convintional/300L & & 3.00 & 8.00 & 10.00 & 9.00 & & 2.50 & 5.00 & 7.00 & 6.00 \\
\hline \multirow{4}{*}{ 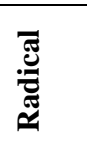 } & EFCO-16/60 L & & 90.00 & 87.00 & 87.00 & 87.00 & & 89.00 & 83.00 & 76.00 & 79.50 \\
\hline & EFCO-16/80 L & & 88.00 & 86.00 & 84.00 & 85.00 & & 89.00 & 82.00 & 76.00 & 79.00 \\
\hline & UNX-18/100 L & & 87.00 & 82.00 & 80.00 & 81.00 & & 88.00 & 81.00 & 70.00 & 75.50 \\
\hline & Convintional/300L & & 86.00 & 80.00 & 78.00 & 89.00 & & 87.00 & 79.00 & 70.00 & 74.50 \\
\hline \multirow{4}{*}{ 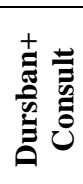 } & EFCO-16/60 L & 86.00 & & 84.00 & 81.00 & 82.50 & 87.00 & & 83.00 & 77.00 & 80.00 \\
\hline & EFCO-16/80 L & 86.00 & & 84.00 & 78.00 & 81.00 & 86.00 & & 82.00 & 76.00 & 79.00 \\
\hline & UNX-18/100 L & 84.00 & & 80.00 & 78.00 & 79.00 & 84.00 & & 80.00 & 74.00 & 77.00 \\
\hline & Convintional/300L & 83.00 & & 80.00 & 76.00 & 78.00 & 80.00 & & 78.00 & 70.00 & 74.00 \\
\hline \multirow{4}{*}{ 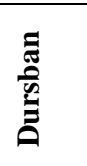 } & EFCO-16/60 L & 78.00 & & 75.00 & 72.00 & 73.50 & 83.00 & & 80.00 & 74.00 & 77.00 \\
\hline & EFCO-16/80 L & 78.00 & & 74.00 & 70.00 & 72.00 & 82.00 & & 79.00 & 71.00 & 75.00 \\
\hline & UNX-18/100 L & 75.00 & & 71.00 & 69.00 & 70.00 & 79.00 & & 78.00 & 70.00 & 74.00 \\
\hline & Convintional/300L & 73.00 & & 70.00 & 65.00 & 67.50 & 76.00 & & 74.00 & 68.00 & 71.00 \\
\hline
\end{tabular}

(knapsack sprayer $225 \mathrm{~L} / \mathrm{ha}$ ) and ultra- low volume( a Fogair sprayer $12.5 \mathrm{~L} / \mathrm{ha}$ ) for control cotton pests using conventional insecticides. Results indicated that, the little difference between the incidence of bollworms pink, spiny and American bollworms and between plots treated with the various sprayer types. Also, the data proved that the low-volume sprayer was better than high volume sprayers for controlling cotton insects. Mambiri, 1987 using Electrodyn, Ulva micron and conventional knapsack sprayers for controlling the cotton pests (specially, Heliothis and Earias spp.). Results indicated that, the highest seed cotton yield increased compared with conventional knapsack sprayer.

Singh, et al. 1987 found that high and low volume treatments to control pink bollworm and spiny bollworm were least effective with an ultra low-volume treatment (ULV). Dashad et al. 2001 evaluate of different sprayer (hydraulic knapsack manual-operated sprayer, KS; hydraulic knapsack manual operated, HI-TECH; hydraulic knapsack manual operated sprayer, KSHT; power operated knapsack sprayer-cummist blower, PS and controlled droplet applicator, CDA. Found that PS sprayer during the vegetative phase of cotton caused the lowest leafhopper 0.96 nymph/leaf and
3.6.Efficiency using different sprayer types on reduction of some predators

Results in Table (5) indicate that ,the highest initial reduction of some predators associated with cotton leafworm and American bollworm larvae in peanut fields were (62.00-64.00), (59.0061.00), (49.00-48.00\%) and (1.00-1.00\%), while using the power Knapsack sprayer (EFCo-16 60L/fed. for Dursban+ Consult, Dursban, Radical and Dipel DF during 2010 and 2011 seasons, respectively.

The lowest initial reduction recorded using the conventional motor sprayer $300 \mathrm{~L} / \mathrm{fed}$. were (48.00-49.00), (58.00-50.00),(37.00-38.0) and $(1.00-1.00 \%)$ for Dursban + Consult, Dursban, Radical and Dipel DF during 2010 and 2011 seasons, respectively.

On the other hand, using Dursban mixed with Consult and Dursban alone gave the highest mean residual effect against of some predator associated both cotton leafworm and American bollworm larvae compared to both Radical and Dipel DF ( 2010 and 2011 seasons). Abd-Allah and Ammar, 2008 tested three sprayers (knapsack sprayer, Solo 22 L/fed., conventional sprayer 200L/fed and knapsack motor sprayer, Arimitsu 25 L/fed. Using two insecticides (primiphos -methyle and achook) against highfly, leafhopper and green stink bug 
Table (5): Reduction percentage of bioinsecticides and conventional insecticides on some predators accessioned of cotton leafworm and American bollworm larvae in peanut bean fields during 2010 and 2011 seasons.

\begin{tabular}{|c|c|c|c|c|c|c|c|c|c|c|c|}
\hline \multirow{3}{*}{\multicolumn{2}{|c|}{ Compound }} & \multicolumn{5}{|c|}{2010} & \multicolumn{5}{|c|}{2011} \\
\hline & & \multicolumn{2}{|c|}{ Initial \% } & \multicolumn{3}{|c|}{ Residual \% } & \multicolumn{2}{|c|}{ Initial\% } & \multicolumn{3}{|c|}{ Residual\% } \\
\hline & & $\begin{array}{c}1 \\
\text { day }\end{array}$ & $\begin{array}{c}3 \\
\text { day }\end{array}$ & $\begin{array}{c}7 \\
\text { day }\end{array}$ & $\begin{array}{c}10 \\
\text { day }\end{array}$ & $\begin{array}{c}\text { Mean } \\
\text { residual }\end{array}$ & $\begin{array}{c}1 \\
\text { day }\end{array}$ & $\begin{array}{c}3 \\
\text { day }\end{array}$ & $\begin{array}{c}7 \\
\text { day }\end{array}$ & $\begin{array}{c}10 \\
\text { day }\end{array}$ & $\begin{array}{c}\text { Mean } \\
\text { residual }\end{array}$ \\
\hline \multirow{4}{*}{ 总 } & EFCO -16/60 L & & 1.00 & 2.00 & 7.00 & 3.50 & & 1.00 & 1.00 & 4.00 & 2.50 \\
\hline & EFCO-16/80 L & & 1.00 & 1.00 & 4.00 & 2.50 & & 1.00 & 1.00 & 3.00 & 2.00 \\
\hline & UNX-18/100 L & & 1.00 & 1.00 & 4.00 & 2.50 & & 1.00 & 1.00 & 3.00 & 2.00 \\
\hline & Convintional/300L & & 1.00 & 1.00 & 3.00 & 2.00 & & 1.00 & 1.00 & 2.00 & 1.50 \\
\hline \multirow{4}{*}{ 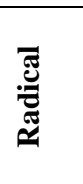 } & EFCO-16/60 L & & 49.00 & 50.00 & 48.00 & 49.00 & & 48.00 & 48.00 & 46.00 & 47.00 \\
\hline & EFCO-16/80 L & & 45.00 & 45.00 & 42.00 & 43.50 & & 46.00 & 46.00 & 40.00 & 42.00 \\
\hline & UNX-18/100 L & & 42.00 & 39.00 & 37.00 & 38.00 & & 41.00 & 37.00 & 37.00 & 37.00 \\
\hline & Convintional/300L & & 39.00 & 37.00 & 37.00 & 37.00 & & 38.00 & 36.00 & 36.00 & 36.00 \\
\hline \multirow{4}{*}{ 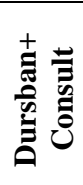 } & EFCO-16/60 L & 62.00 & & 69.00 & 61.00 & 65.00 & 64.00 & & 67.00 & 60.00 & 63.50 \\
\hline & EFCO-16/80 L & 59.00 & & 62.00 & 55.00 & 58.50 & 59.00 & & 64.00 & 60.00 & 62.00 \\
\hline & UNX-18/100 L & 52.00 & & 64.00 & 60.00 & 62.00 & 51.00 & & 65.00 & 60.00 & 62.50 \\
\hline & Convintional/300L & 48.00 & & 61.00 & 60.00 & 62.50 & 49.00 & & 63.00 & 56.00 & 59.50 \\
\hline \multirow{4}{*}{ 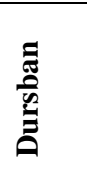 } & EFCO-16/60 L & 59.00 & & 56.00 & 53.00 & 54.50 & 61.00 & & 57.00 & 54.00 & 55.50 \\
\hline & EFCO-16/80 L & 59.00 & & 56.00 & 52.00 & 54.00 & 59.00 & & 55.00 & 53.00 & 54.00 \\
\hline & UNX-18/100 L & 59.00 & & 54.00 & 50.00 & 52.00 & 53.00 & & 50.00 & 50.00 & 50.00 \\
\hline & Convintional/300L & 58.00 & & 51.00 & 50.00 & 50.50 & 53.00 & & 50.00 & 49.00 & 49.50 \\
\hline
\end{tabular}

pests and common green lacewing, Chrysoperla carnea as a high number of natural enemies on cowpea, eggplant and okra plants. Results indicated that insecticides used were moderate hazardous for $C$. carnea specially with a shook compound. Also, Abd-Allah et al., (2011), found that all the tested insecticides (chemisol, mospilan,Sumicidin, MTI-446 and jojoba) exhibited a moderate hazardous effect on Scyminus sp., Orius sp. and Syrphus corolla after the $1^{\text {st }} \& 2^{\text {nd }}$ sprays and high hazardous effect on Paederus alfierii, while mospilan, MTI-446 and jojoba proved to be the most save compounds for predators and parasites.

\section{REFERENCES}

Abd-Allah A.A.A. and Ammar A.E. (2008). Comparative studies between a bio and chemical insecticides sprayed with three tools of application on certain vegetable crops against some insects at two villages in Sharkia Governorate. Agric. Res. J. Suez. Cannal Univ. 8 (1):103-114.

Abd-Allah A.A.A., Al- Shannaf H.M. H., Ammar A.A. and Megahed H.A. (2011). Insecticidal efficiency of some chemical compounds against some piercing - sucking insect infesting squash plants and its associated natural enemies using three spraying tools. Zagazig J. Agric., Res., 38 (4) 1011 - 1029.

Abou-Amer A.M. (1993). Spray spectrum of insecticide deposits on cotton canopy after using different spraying techniques. Ph.D. Thesis, Fac. of Agric., Cairo Univ. Egypt, $179 \mathrm{pp}$.

Alford D. V. (2000). Pest and disease management hand book. British Crop Protection Council, Blackwell Science, Oxoford, 615 pp.

Al-Shannaf H.M.H. (2007). The efficiency of some compounds against egg-masses of Spodoptera littoralis (Boisd.) and their predators on cotton fields. J. Agric. Sci., Mansoura Univ. 32 (2): 1487-1494.

Amin T. R. (2007). The effect of host plants on susceptibility of the cotton leafworm, Spodoptera littoralis (Boisd.) to insecticidal treatment. Egypt. J. Agric. Res., 85 (6):20052015.

Ammar A.E. (2003). Studies on certain techniques for pesticide application. PH. D. Thesis, Fac. Of Agric., Zagazig Univ. Egypt 169 pp.

Ammar A.E. (2007). Conventional and developmental spraying techniques for controlling whightfly attacking tomato plants in greenhouses. Egypt. J. Agric. Res. ,85 (1):67-75.

Badr N.A., Hindy M.A., Negm M.F., Abd-El-

Haleim S.M. (1999). Performance of ground low-volume spring machines for controlling cotton leafworm larvae on clover plants. Egypt .J. Agric. Res. 77 (3);1035-1043.

Chhuneja P.K., Harcharan -Singh and Singh H. (1999). Economics of spray technology for pest control on cotton. J. Insect. Sci., 4 (2):200-202. 
Dashad S. S., Malipatil M. V., Sharma P. D. and Chaudhary O.P. (2001). Relative performance of different sprayers, nozzles and spray volumes in controlling insect pests of cotton in Haryana. Crop-Res.-Hisar. 21 (3):324-331.

Gehan G.A. (2000). Evaluation of the performance of epands sprayers. M.Sc. Thesis, Fac. Agric.,Zagazig Univ. 43 - 44 pp.

Henderson C. F. and Telton E.W. (1955). Tests with acaricides against the brown wheat mite. J. Econ. Entomol., 48: 157-161.

Hindy M.A.(1998). Evaluation of certain common used spraying techniques for controlling cotton leafworm on cabbage with Lannate insecticide. $7^{\text {th }}$ Conf. Agric. Dev. Res.,Fac. Agric., Ain Shams Univ., Cairo, December 1517.(Annal Agric Sci., Sp. Issue 1, 213-221).

Hindy M.A., Abd-El Haleim S.M., Badr M.A. and El-Sisi A.G. (1999). Evaluation of some locally formulated natural products and different ground spraying equipments for controlling cotton leafworm in clover seedlings. Fayoum J. Agric Res. \&Dev. 13 (2): 41-51.

Mambiri A. M. (1987). Evaluation of some crop sprayers in the application of insecticides on cotton in Kenya. Tropical Pest Management, 33 (3):189-191.

Pearson E.O. (1958). The insect pests of cotton in tropical Africa. Empire cotton growing corporation and commonwealth institute of entomology, london, pp. 142-162.

Singh H., Chhuneja P.K. and Sigh H. (1987). Comparative performance of h.v.,l.v. and u.l.v. sprayers for the control of cotton. Tropical Pests Management, 33 (1):73-80.

Vadivelu S., Rao,Pvs and Balasubramanian M. (1986). Efficacy of different types of sprays on the control of cotton pests. J. Pesticide, 20 (10):33-34.

$$
\begin{aligned}
& \text { دراسة عن استخدام ادوات رش متتوعة لمكافحة دودة ورق القطن ودودة اللوز الامريكية فى حقول الفول السودانى } \\
& \text { حاتم محمد حاتم الشناف ـ عبد المجيد السيد عمار } \\
& \text { معهد بحوث وقاية النباتات - مركز البحوث الزراعية ـ الدقى - جيزة- مصر }
\end{aligned}
$$

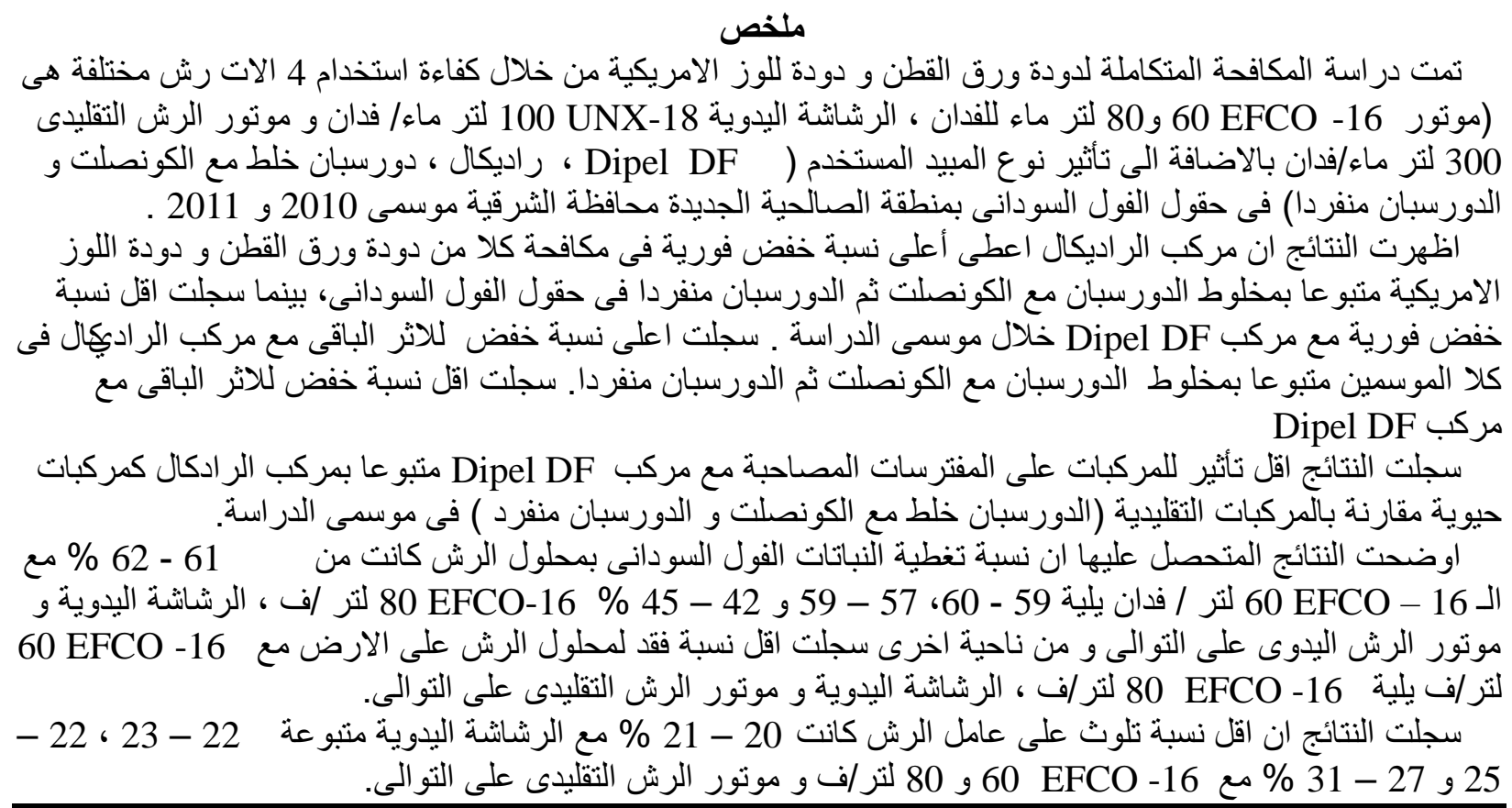

